\title{
Spanish in Contact with Korean: New Insights into Language Switching*
}

SILVIA KIM**

Recepción: 10 de marzo de 2020

Aprobación: 7 de junio de 2020

How to cite this article: Kim, S. (2020). Spanish in Contact with Korean: New Insights into Language Switching. Cuadernos de Lingüística Hispánica, (36), 155-180.

$10.19053 / 0121053 X . n 36.2020 .11301$

* Full research article.

** Received her M.A. in Spanish Linguistics from Seoul National University and is currently a PhD student in Linguistics at the University of Southern California. Her research focus is sentence processing in psycholinguistics. Her recent work is mainly centered on Spanish-Korean code-switching, English-Korean code-switching, bilingualism, and second language acquisition. E-mail: silbiaki@usc.edu @https://orcid.org/0000-0002-7720-6897 


\section{Abstract}

'Code-switching' (CS) refers to language-mixing where individuals who speak two or more languages switch from one to another, often mid-sentence. Several morphosyntactic constraints governing when switches happen have been proposed in prior work, mostly on Spanish-English CS (e.g. Timm, 1975; Pfaff, 1979; Poplack, 1980). However, what happens when the languages are typologically different? This is the case with SpanishKorean CS, which has not been systematically investigated. Korean and Spanish differ in many respects, including clause structure/word order, absence/presence of articles, and morphology (Korean: agglutinative, Spanish: fusional) (Kwon, 2012; Bosque, Demonte, Lázaro, Pavón \& Española, 1999). For the present study, balanced Spanish-Korean bilinguals were interviewed to obtain a naturalistic corpus of CS. Strikingly, we find that many constraints proposed for Spanish-English CS do not hold for Spanish-Korean. Specifically, there are three main ways that Spanish-Korean CS violates the constraints proposed for Spanish-English: (i) in contexts involving word order/clause structure, (ii) on the level of nouns and (iii) on the level of morphemes. Crucially, the violations are not random: We suggest that they stem from the typological differences between Korean and Spanish. This work highlights the empirical and theoretical benefits of including typologically diverse language pairs when investigating CS.

Keywords: Spanish-Korean, code-switching, bilingualism, typology, Free Morpheme Constraint, Functional Head Constraint.

\section{Español en contacto con coreano: nuevas apreciaciones en el cambio de idioma}

\section{Resumen}

El cambio de código ('code-switching', CS) se refiere a la mezcla de idiomas donde las personas que hablan dos o más idiomas cambian de una a otra. Los trabajos sobre CS español-inglés han identificado varias restricciones morfosintácticas que gobiernan cuando ocurren los cambios (por ejemplo, Timm, 1975; Pfaff, 1979; Poplack, 1980; sin embargo, ¿qué sucede cuando los idiomas son tipológicamente diferentes? Este es el caso del CS español-coreano, que no se ha investigado sistemáticamente. Estos idiomas difieren en muchos aspectos, incluyendo (i) estructura de la cláusula/orden de las palabras, (ii) ausencia/presencia de artículos y (iii) morfología (coreano: aglutinante, español: fusional) (Kwon, 2012; Bosque et al., 1999). Para este estudio, entrevistamos a bilingües hispano-coreanos para obtener un corpus naturalista. Sorprendentemente, encontramos que muchas restricciones propuestas para el CS español-inglés no son válidas para el español-coreano. Hay tres maneras en que el CS español-coreano viola las restricciones: 
(i) en contextos que involucran la estructura de cláusulas, (ii) uso de sustantivos y (iii) en el nivel de morfemas. Crucialmente, las violaciones no son aleatorias: sugerimos que provienen de las diferencias tipológicas. Este trabajo destaca los beneficios empíricos y teóricos de incluir pares de idiomas tipológicamente diversos al investigar el CS.

Palabras claves: español-coreano, cambio de código, bilingüismo, tipología, restricción del morfema libre, restricción del núcleo funcional.

\section{Espagnol et coréen en contact: nouvelles perceptions sur le changement de code}

\section{Résumé}

Le changement de code (CC) fait référence aux interférences de langue lorsque les personnes qui parlent deux langues ou plus passent de l'une à l'autre. Les travaux sur l'espagnol-anglais CC ont identifié plusieurs contraintes syntaxiques (morpho) qui guident les changements (par exemple, Timm, 1975; Pfaff, 1979; Poplack, 1980). Cependant, que se passe-t-il lorsque les langues en question sont typologiquement différentes? C'est le cas du CC hispano-coréen, qui n'a pas fait l'objet d'une recherche systématique. Ces langues diffèrent à bien des égards, notamment en ce qui concerne (i) la structure des clauses / l'ordre des mots, (ii) l'absence / la présence d'articles, et (iii) la morphologie (coréen: classeur, espagnol: fusionnel) (Kwon, 2012; Bosque y Demonte, 1999). Pour cette étude, nous avons interviewé des bilingues espagnol-coréen afin d'obtenir un corpus naturaliste. Nous avons constaté que de nombreuses restrictions proposées pour l'espagnol-anglais CC ne sont pas valables pour l'espagnol-coréen. Le CC hispano-coréen va au-delà des restrictions de trois manières: (i) dans des contextes impliquant la structure de la clause, (ii) l'utilisation de noms et (iii) au niveau des morphèmes. Les violations ne sont surtout pas aléatoires: nous suggérons qu'elles proviennent de différences typologiques. Cet article souligne les avantages empiriques et théoriques de l'inclusion de paires de langues typologiquement diverses lors de l'étude du CC.

Mots-clés: espagnol-coréen, changement de code (CC), bilinguisme, typologie 


\section{Espanhol e coreano em contato: novas percepções sobre mudança de código}

\section{Resumo}

A troca de código ('code-switching', CS) refere-se à mistura de idiomas em que as pessoas que falam dois ou mais idiomas alternam de um para o outro. Trabalhos em CS espanhol-inglês identificaram várias restrições (morfo) sintáticas que governam quando ocorrem mudanças (por exemplo, Timm, 1975; Pfaff, 1979; Poplack, 1980). No entanto, o que acontece quando os idiomas são tipo logicamente diferentes? É 0 caso do CS espanhol-coreano, que não foi sistematicamente investigado. Esses idiomas diferem de várias maneiras, incluindo (i) estrutura da cláusula / ordem das palavras, (ii) ausência / presença de artigos e (iii) morfologia (coreano: fichário, espanhol: fusional) (Kwon, 2012; Bosque y Demonte, 1999). Para este estudo, entrevistamos bilíngues espanhol-coreanos para obter um corpus naturalista. Surpreendentemente, descobrimos que muitas restrições propostas para CS espanhol-inglês não são válidas para espanholcoreano. Há três maneiras pelas quais o CS espanhol-coreano viola as restrições: (i) em contextos que envolvem a estrutura da cláusula, (ii) uso de substantivos e (iii) no nível dos morfemas. Fundamentalmente, as violações não são aleatórias: sugerimos que elas resultam de diferenças tipológicas. Este artigo destaca os benefícios empíricos e teóricos da inclusão de pares de idiomas tipologicamente diversos ao investigar a CS.

Palavras-chave: espanhol-coreano, alteração de código, bilinguismo, tipologia 


\section{Introduction}

Today, more than half of the world's population is bilingual or multilingual (e.g. Simpson, 2019). Thus, theories of linguistic competence should strive to capture the linguistic behavior not only of monolingual but also of multilingual speakers. People sometimes switch from one language to another in the span of a conversation; this phenomenon is called code-switching (henceforth "CS"). Code-switching refers to language-mixing where someone who speaks two or more languages switches from one to another. How code-switching occurs changes depending on the location and social context. Although some early work regarded code-switching as syntactically unconstrained, more recent work has focused on identifying the grammatical constraints that determine when switches can happen.

Prior work on code-switching has been abundantly done on Spanish-English and has identified several morpho-syntactic constraints that govern the possibility of switching from one language to another (e.g. Timm, 1975; Pfaff, 1979; Poplack among many others). Indeed, Spanish-English code-switching is an important social phenomenon due to the large population of Spanish-English bilinguals in the United States. However, it is worth noting that Spanish and English are two related and typologically fairly similar languages. What happens when the two languages involved in code-switching are typologically unrelated and have different typological properties? This is the case with Spanish-Korean code-switching, which - to the best of our knowledge- has not previously been systematically investigated.

Spanish and Korean differ in many respects, including word order and morphology (Spanish: fusional, Korean: agglutinative) (e.g. Kwon, 2012; Bosque \& Demonte, 1999). To better understand the grammatical constraints on code-switching, we investigate (a) whether the linguistic constraints proposed for Spanish-English codeswitching extend to Spanish-Korean and (b) whether Spanish-Korean code-switching exhibits other kinds of constraints beyond those proposed for Spanish-English, and (c) if so, how they are related to the typological differences between the languages. Our empirical aim is to develop a corpus of code-switching for a language pair that has not been systematically investigated in prior code-switching work. This paper is organized as follows: Section 2 reviews definitions and different types of CS. Sections 3 and 
4 present relevant previous work on CS and state our research questions. In Section 5, we present naturalistic Spanish-Korean CS examples and discuss what they tell us about the constraints at play in Spanish-Korean CS. Section 6 is the general discussion ${ }^{1}$.

\section{A Closer Look at Code-Switching}

Code-switching is language-mixing where individuals who speak two languages switch from one to another, often mid-sentence: "Code-switching is the alternation of two languages within a single discourse, sentence or constituent" (Poplack 1980, p. 583): Code-switching typically happens in situations where both the speaker and the listener are highly bilingual in both of the languages. However, it is important to acknowledge that it can sometimes be hard to distinguish between code-switching and lexical borrowing. Lexical borrowing refers to a situation where a single word or frozen phrase from language $X$ is used in language $\mathrm{Y}$ (the speaker's native language), typically assimilates phonologically to language $\mathrm{Y}$, and fully assimilates into the grammatical system of language $\mathrm{Y}$ (e.g. Poplack, 1980; Pfaff, 1979, Gumperz 1977). Unlike CS, lexical borrowing can happen in contexts where the speaker is not proficient in language $\mathrm{Y}$.

\section{Taipeo las cartas.}

\section{'(I) type the $e_{\text {-PL letters'. (English and Spanish; Pfaff, 1979, p. 296) }}$}

For example, according to Pfaff (1979), (1) involves lexical borrowing because the English word 'type' has been modified to fit the phonological and morphological properties of Spanish, becoming 'taipear'. In the present study we only focus on data that can be analyzed as code-switching, not lexical borrowing, as indicated by the phonological and morphosyntactic behavior of the linguistic elements.

Relatedly, in the present paper we only consider data from speakers who have high proficiency/native-like proficiency in both languages (i.e. we view CS as requiring an advanced level of bilingualism, following Pfaff, 1979) and where the juxtaposition of two languages impacts the internal syntactic system. It is worthwhile noting here that bilingualism is a continuum: people may have different levels of proficiency in the two languages (e.g. Weinreich, 1953; Fishman, 1977; Cummins 1981, among others). Typically, CS research has focused on balanced bilinguals, mostly simultaneous bilinguals

1 I would like to thank the audience at the 27th Conference on Spanish in the US \& 12 Conference on Spanish in Contact with Other Languages for comments and feedback. Thanks also to Elsi Kaiser for in-depth feedback on this paper, as well as many helpful suggestions regarding the data. 
who learned both languages from birth - and this is also the population that we focus on in this paper.

Prior work has identified CS as a phenomenon that can occur on multiple levels (e.g. Poplack, 1980, Simpson 2019). In the current study, we focus on intra-sentential $C S$, i.e. switches that happen within clause boundaries. This type of CS allows us to gain insights into the interplay of two different grammatical systems.

Although there is an extensive literature regarding CS, most of this research has focused on Spanish-English switching, and most of the constraints that have been proposed regarding code-switching are largely based on these languages. This raises the question of whether these constraints are also relevant for Spanish-Korean CS, given how typologically different Korean (Koreanic) is from Spanish and English (both IndoEuropean). For example, on the level of word order, Korean is a head-final language, whereas Spanish and English are head-initial. Table 1 summarizes some of the typological differences between Spanish and Korean.

Table 1. Examples of some differences between Spanish and Korean

\begin{tabular}{|l|l|}
\hline \multicolumn{1}{|c|}{ Spanish } & \multicolumn{1}{c|}{ Korean } \\
\hline - Indo-European language & - Language isolate (Koreanic) \\
- Head initial & - Head final \\
- Fuso order & - SoV order \\
- Presenal in morphology of articles (e.g. & - Agglutinative in morphology \\
- $e l$, la $)$ & - Articleless language \\
Latin script & Korean script (Hangul) \\
\hline
\end{tabular}

\section{Research on Code-Switching}

Most of the early work in CS focused on sociolinguistic factors or morpho-syntactic restrictions (e.g., Fishman et al., 1971; Timm, 1975; Pfaff, 1979; Poplack, 1980; Sankoff \& Poplack, 1981; Woolford, 1983; Joshi, 1985; Belazi, Rubin \& Toribio, 1994, among many others). After this early period of sociolinguistic work on CS, the research focus broadened to also include investigation of structural constraints. These structural constraints were often explicitly or implicitly assumed to be universal (applicable to all language pairs) e.g. by Timm (1975). In the next sections, we review some of these proposed structural constraints in more detail, discuss some initial counterexamples already presented in the 
literature, and discuss new data from our Spanish-Korean corpus that provides additional counter-examples for these constraints.

In this paper, we use data from a naturalistic corpus, in line with much of the earlier work on CS, but we broaden the domain of investigation to an under-researched language pair. Naturalistic data has the advantage of providing an indication of what kinds of structures code-switchers normally produce. However, naturalistic corpus work can be complemented by experimental research. Indeed, there has been an increase in experimental work on CS in recent years, including comparisons between different bilingual groups, including second language learners (L2 speakers) and heritage speakers (e.g. Potowski \& Bolyanatz, 2012; Giancaspro, 2013; Alexiadou \& Lohndal, 2018, among many others). Although we use naturalistic corpus data and focus on bilinguals who are highly proficient in both languages, we regard experimental work and work on other bilingual populations as important research avenues as well.

\section{Research Questions}

Taken together, previous studies have left a large number of open questions regarding how different bilingual groups code-switch and what the constraints are, if any. We investigate the following questions: (1) Universality of code-switching constraints: Do the linguistic constraints proposed for Spanish-English code-switching extend to Spanish-Korean code-switching? We may find differences in Spanish-Korean switching given that Spanish and Korean are typologically very different. (2) Properties of SpanishKorean CS: Is Spanish-Korean CS subject to other kinds of constraints? If so, how do these constraints relate to the typological differences between the languages? Our empirical aim is to develop a corpus of Spanish-Korean CS because this pair of languages has not been systematically investigated in prior CS work.

\section{Spanish-Korean Code-Switching Data}

We may wonder what happens when two typologically different languages are involved in code-switching. In this section, we will analyze the collected data from SpanishKorean bilinguals and compare it with previous studies from Spanish-English CS. The sections below are structured as follows: we first explain how we collected our corpus data and the participants' overall characteristics. We then provide definitions and examples of the linguistic constraints proposed for Spanish-English CS, followed by counterexamples from other language pairs. We then present examples of Spanish-Korean CS and discuss how these challenge and go beyond the constraints proposed in earlier work. 


\section{Methodology (Data Collection and Participants)}

The data used in the investigation was naturalistic data, meaning that it was collected in natural contexts. All code-switchers were university students and native speakers of Spanish and Korean. Most of the participants $(n=46)$ reported they had learned both languages since birth. Many were Korean descendants that had lived in Hispanic countries such as Spain, Costa Rica, Guatemala, Peru, Ecuador, Mexico, El Salvador, Dominican Republic, Venezuela, Colombia and Paraguay. (We collected data from different Spanish speaking countries to see if dialectal differences influence code-switching. However, no crucial differences were found for dialects.) Out of the 46 participants who were interviewed, we included explicit examples from 17 speakers in this paper. These 17 participants are from 9 different Hispanic countries ( 8 male and 9 female speakers). The average age of participants was 23.47 years (SD 3.43 yrs.). They had lived an average of 19.74 years in a Spanish-speaking country (SD 2.62 yrs.). Participants had lived in Korea for 3.74 years on average (SD 1.59 yrs.).

We took into consideration several criteria for all participants: preferably native bilinguals (from birth) or people who learned a second language from a very young age, people who have lived in both Spanish and Korean environments, and people with constant exposure to both languages, and continuous use of both languages. The majority were second generation speakers born and raised in a Latin American country or 1.5 generation immigrants who were born in Korea but raised in a Latin American country. All of participants had moved back to Korea for their university studies (in either undergraduate or graduate programs). The data was collected between January and April 2016. It includes audio recordings of natural conversations, text messages, in-person interviews, comments and posts from social networking sites, etc. Topics covered include attitudes towards Korean or foreign culture, school- or work-related topics, daily life and major issues in Korea at the time of the interview. We collected both spoken and written data. During the interviews, the interviewer also used codeswitching to elicit natural CS.

In the subsequent sections, we consider whether two of the primary constraints proposed in prior work - (i) the Free Morpheme Constraint (FMC) and (ii) the Functional Head Constraint (FHC) - are followed in Spanish-Korean CS. As we will see, SpanishKorean behaves differently from Spanish-English CS but has many similarities with Spanish-Náhuatl CS. 


\section{Free Morpheme Constraint (FMC): Definition and Counterexamples}

One of the few theories argued to be universal is the Free Morpheme Constraint (FMC) by Poplack (1980). Indeed, the FMC was assumed to be universal for almost three decades until MacSwan (1999) provided evidence from Spanish-Náhuatl CS against the FMC. (Náhuatl is an Uta-Aztecan language spoken in Mexico.) According to the Free Morpheme Constraint (FMC), "Codes may be switched after any constituent in discourse provided that constituent is not a bound morpheme." (Poplack, 1980, p. 585). E.g. switching from an English verb root to the Spanish gerund ending ('-ing') results in ungrammaticality (ex. 2-3).

(2) *Eat-iendo

*Run-eando
(Poplack, 1980, p. 586) (3)

(Sankoff \& Poplack, 1981, p. 5)

However, MacSwan (1999) shows that in Spanish-Náhuatl, the FMC does not apply: Word-internal switches are acceptable. As in (4), adding Náhuatl prefixes and suffixes to the Spanish infinitival golpear (hit) does not result in ungrammaticality - contrary to what is predicted by the FMC. In addition to verb-based switches involving bound morphemes, it is also possible to switch between nouns and bound morphemes, as shown in (5). (Náhuatl is italicized, Spanish is bolded.)

(4) Ne onikgolpearoa tlakatl.

IPAST-3S-30s-hit-VSF IN man-NSF

'I hit the man.' (MacSwan, 1999, p. 133)

\section{5) Nowelti okimak nohermano.}

My-sister PAST-3S-30s-give my-brother

'My sister hit my brother.' (MacSwan, 1999, pp. 133-134)

These violations of the Free Morpheme Constraint also happen in Spanish-Korean CS. In our spoken corpus (in-person interviews), participants naturally produced language switches involving bound morphemes. These switches often involved the Spanish plural marker '-s.' For example, (6) and (7) show Korean nouns with the Spanish plural '-s' (as well as a preceding Spanish plural possessive mis 'myplural'. Note that the Korean words in the data reported here were pronounced following Korean phonology. This shows they can be categorized as codeswitching, not lexical borrowing (see e.g. Gumperz, 1977; 
Pfaff, 1979; Poplack, 1980, on the fact that borrowings are adapted to the phonology of the matrix language, in this case Spanish). In the present discussion, all of the relevant examples can be classified as involving CS. We use Yale transcription for Korean (Martin, 1992). In addition to nouns in one language occurring with bound morphemes from the other language, participants also produced Korean verb roots with Spanish verbal endings. Switches between verb stem and bound morpheme happened frequently with the Spanish infinitival ending 'ear' as in (8), as well as the gerund 'ando' which yields progressive forms, e.g. (9) and (10). Throughout this paper, when reporting examples of Spanish-Korean CS, we use italics for Korean and regular font for Spanish.

(6) Nadie de mis $\boldsymbol{c h i n k w u - s ~ h a ~ c h w i c i k h a y s s e ~}$ [Costa Rica]

Nadie de mis [Ghingu]s ha [6hwicikhes*^].

'None of my friends have gotten a job.'

(7) Mis cenkong-s son muy difíciles de ttalaka.

[Costa Rica]

Mis [Gূngoy]s son muy difíciles de [ $t^{*}$ araga].

'My major courses are very hard to follow.'

(8) Necesito olmkye-ear mi cim al kiswuksa.

[Costa Rica]

Necesito [omgj^]ear mi [6im] al [kisuks*a].

'I need to move my belongings to the dormitory.'

(9) Dice que todavía está meke-eando.

[Peru]

Dice que todavía está [maga]eando.

'He says that (he) is still eating.'

(10) Ella pasa nolta-ando porque es ilhaknyen.

[Peru]

Ella pasa [nolda]ando porque es [iraynjın].

'She keeps playing because (she) is a freshman.'

Functional Head Constraint (FHC): Definition and Counterexamples

After Chomsky's (1993) proposal of the Government-Binding Theory (GB Theory), linguists used the feature checking process to explain code-switching derivations as 
well. Belazi, Rubin and Toribio (1994) suggest two universal syntactic constraints on intrasentential CS: (i) the Functional Head Constraint (FHC) that posits language as a feature and (ii) the Word-Grammar Integrity Corollary that requires all words of a language to obey that language's grammar in code-switching contexts. In principle, they adopt Abney's (1987) f-selection to explain that words/morphemes bear a language feature that needs to be checked.

Our focus here is on the Functional Head Constraint (FHC), which states that "The language feature of the complement f-selected by a functional head, like all other relevant features, must match the corresponding feature of that functional head" (Belazi et al., 1994 , p. 228). Therefore, the feature language, for instance, [ \pm Spanish], [ \pm English], or [ \pm Korean], must be the same in the functional head as its complement. Consider the following example:

(11) a. *The police officers have visto un ladrón.

$$
\text { b. *Los policías han seen a thief. ～(Belazi et al., 1994, p. 230) }
$$

The switch between the auxiliary verb (e.g. have) and the main verb (e.g. visto 'seen') results in an ungrammatical structure for the following reason: Since Aux is the functional head, the main verb should follow its language feature, meaning that the auxiliary and main verb should be in the same language.

Nevertheless, prior work already identified counterexamples that violate the Functional Head Constraint, with language switches occurring in the boundary of the functional head and its complement (e.g. Mahootian \& Santorini, 1996 on Farsi-English, and Nishimura 1985 on Japanese-English). In the following subsections, we show that Spanish-Korean CS also violates the FHC. We consider seven different structures that have been argued to involve the FHC, namely (i) aux verb/modal verb + main verb, (ii) verbal periphrasis, (iii) connectives, (iv) complementizers, (v) determiners + noun phrases, (vi) quantifiers, (vii) negation + verb. As we will see, Spanish-Korean CS seems to violate the FHC in all of these configurations.

\section{Auxiliary/Modal Verb + Main Verb}

According to the FHC, a language switch between an auxiliary or modal verb and the main verb should not be possible. This is shown by the ungrammaticality of ex. (12) (French-Tunisian Arabic) and ex. (13-14) (English-Spanish).

(12) *Je serai sae:fir-t fi-l- $\square$ ašra. 
'I will have gone by ten o'clock.' (Belazi et al., 1994, p. 225)

(13) *Five of my cousins have completado estudios universitarios.

(Toribio, 2001, p. 206)

(14) *El candidato puede prepare his remarks during the flight.

(Toribio, 2001, p. 209)

However, other researchers, including Pfaff (1979), Poplack (1981), and Mahootian (1993) presented counterexamples (ex. 15-16). MacSwan (1999) also argues against the full version of the FHC for Spanish-Náhuatl code-switching, though he does identify some more complex constraints at play.

(15) ... as they're ablandando, ya que está un poquito birviendo... (Poplack, 1981, p. 177)

(16) Estaba training para pelear. (Pfaff, 1979, p. 296)

Our corpus data shows that in Spanish-Korean code-switching, both modals and auxiliaries violate the FMC. As shown in (17) and (18), participants switch between modal and main verbs.

(17) ¿Puedes ollye-ear el documento?

[Peru]

'Can you upload the document?'

(18) ¿Quién me puede nolacwe después de swuep?

[Ecuador]

'Who can play with me after class?'

Data for auxiliaries is shown in (19-21). (We consider Korean 'bata'2 and its derivate forms as an equivalent of the verb 'do' in English.) Participants switched naturally between the auxiliary and the main verb. Ex. (19-20) use the auxiliary in the Korean form, ex. (21) uses the Spanish auxiliary 'estar'.

(19) Nalul aplastar-haysse.

[Costa Rica]

2 Syntactically, hata is a light verb, and can function akin to auxiliaries in English and Spanish (e.g. Chan, 2008; Nishimura \& Yoon, 1998). However, there is still debate among linguists about whether hata should be analyzed as an auxiliary/modal verb that selects a verb phrase (VP) or as an adjunct of a main verb. 
'He crusbed me.'

(20) Bañar-bako después me dormí.

[Costa Rica]

'(I) showered, and then I fell asleep.

(21) ¿Estás cwunpibay?

[Guatemala]

\section{'Are you getting ready?'}

\section{Verbal Periphrasis}

Another area where there is debate regarding the FHC is in switches in verbal periphrasis constructions, for example between 'to' and its infinitival complement (e.g. [has to] [read]). Timm (1975) claims that these kinds of switches are not permitted, but Poplack (1981) disagrees, based on examples like (22) where there is a switch between 'have to' and 'dar' (give-INF). An equivalent form of this construction is not available in Korean, but we find that in our corpus, a language switch can occur between any verbal periphrasis, such as 'have to' + infinitive (in Spanish: expressed with the complementizer $q u e$, i.e. tener que + infinitive) or 'go' + infinitive (ir $a+$ infinitive) (ex. 23-24).

(22) ... you have to dar de l'ala pa' comer de la pechuga. (Poplack, 1981, p. 174)

(23) Tengo que ceyponbay los kyocays.

[Colombia]

'I have to bind my teaching materials.'

(24) Vamos a kele.

[Mexico]

\section{'Let's go for a walk.'}

\section{Connectives}

Prior work disagrees about whether language switches can occur after a connective, before the next clause. According to Gumperz (1977), the language of the connective (e.g. and, but, because) should match the language of the following clause, as in (25). However, Sankoff and Poplack (1981) and MacSwan (1999) use examples like (26-27) to argue that it is not necessary for the connective to be in the same language as the following phrase:

(25) a. I was reading a book $\boldsymbol{y}$ ella estaba trabajando. (Gumperz, 1977, p. 25)

b. I wanted to stop smoking pero no pude. 
c. John stayed at home porque su esposa estaba en el trabajo.

(26) I seen everything 'cause no cogí na'. (Sankoff \& Poplack, 1981, p. 6)

(27) Onikitak se ichpochtle, iwan le pregunté dónde está la iglesia.

'I saw a girl, and I asked her where the church is. (MacSwan, 1999, p. 110)

Our data shows the same pattern, as the Spanish-Korean bilinguals sometimes switch between the connective and the following clause: Ex. (28-29) are examples of the connective being in a different language than the following subordinate phrase.

(28) Si vamos en carro puede que makhye porque achiminikka. [ Costa Rica] 'If we go by car, there might be traffic because it is morning.'

(29) Tengo que hacerlo otra vez, pero ceytaylo.

[Costa Rica]

'I have to do it again, but correctly.'

\section{Complementizers}

Another domain where the Functional Head Constraint is claimed to rule out switches is between the complementizer (Comp, that/que) and a subordinate clause (Belazi, Rubin \& Toribio, 1994). According to the FHC, the Comp should be in the same language as the subordinate clause, as in (30a) and (30b). However, MacSwan (1999)'s Spanish-Náhuatl CS data shows switches where the Comp is in Spanish while the subordinate clause is in Náhuatl, as well as switches where the Comp is in Náhuatl and the subordinate clause is in Spanish (ex. 31-32)

(30) a. The professor said que el estudiante babía recibido una $A$.

b. El profesor dijo that the student had received an A.

c. *The professor said that el estudiante habia recibido una A.

d. *El profesor dijo que the student had received an A.

(31) Le dije que kitlasojtla in Juan sikpanoah.

(Belazi et al., 1994, p. 224)

'I told him that she loves Juan a lot'.

(32) Nikchia ke compres ropa. 
'I want you to buy some clothes'. (MacSwan, 1999, pp. 112-113)

Our Spanish-Korean CS data shows the same pattern. There seem to be no restrictions since the subordinate clause can be in either language after the Comp (see ex. 33-34). Even though Comp is a functional head, our data suggests it does not determine the language of the subsequent subordinate phrase.

(33) Ella le dijo que pyengwen kayatway.

[El Salvador]

'She told him that she bas to go to the bospital.'

(34) Fui al caykemsa y me di cuenta que manbi thullyesse. [Costa Rica]

'I went to the reexamination and I realized that I made many mistakes.'

\section{Determiners + NP}

The Functional Head Constraint also rules out switches between a determiner (article) and its noun. Thus, ex. (35) is considered ungrammatical because ' $a$ ' is the head so the following noun should also be in English. However, many researchers have noticed that speakers make frequent switches at this boundary (Poplack, 1981; MacSwan, 1999; Choi, 1991; Yoon, 1992), as shown in ex. (36-38).

(35) *He is a demonio.

(Belazi et al., 1994, p. 227)

(36) Where are they, los language things?

(Poplack, 1981, p. 175)

(37) I command you to do the nokum!

'I command you to do the recording!'

(Choi, 1991, p. 889)

(38) System-i kantanhae.

'(The) system is simple'.

(Yoon, 1992, p. 439)

Ex. (36) shows a determiner in Spanish followed by a noun in English. Ex. (37-38) represent switches between English-Korean: example (37) has a determiner in English whereas the example (38) has a case marker in Korean and in postnominal position. ${ }^{3}$

3 Although Korean has no determiners that show definiteness, it uses case particles in postnominal position to indicate definiteness (Osawa, 1998). For this reason, Chan (2008) treats the nominative and accusative case particle of Korean and Japanese as determiners. We will follow this proposal. 
MacSwan (1999) also shows that there are no restrictions between determiners and nouns using data from Spanish-Náhuatl:

(39) Neka hombre kikoas se kalli.

'That man will buy a house.'

(40) Tengo un konetl.

'I have a son.' (MacSwan, 1999, p. 124)

Switches between determiners and nouns are also possible in Spanish-Korean (ex. 41-42). In fact, they are actually one of the most commonly occurring switches. We hypothesize that, because the Korean language has no articles, bilingual speakers have the tendency to add Spanish articles to Korean nouns. This can be seen as an influence from Spanish since determiners are always needed except in the case of a noun phrase modified by an adjective, a coordinated phrase, or a subject in post-verbal position. Therefore, the inclination to use determiners is very high:

(41) El umsik está muy cca.

[Costa Rica]

'The food is very salty'.

(42) La acwumma del kakey me dio sepisu.

[Ecuador]

'The lady from the store gave me free food'.

\subsection{Quantifiers}

Similar to what is claimed for articles, the FHC also predicts no switches to be possible between quantifiers and nouns (e.g. [many] [students]). This is because Belazi, Rubin, and Toribio (1994) consider quantifiers to be functional heads, thereby prohibiting a language switch of the type in (43). However, this restriction does not appear to hold in English-Farsi code-switching (Mahootian, 1993), as shown in (44).

(43) *Pocos students finished the exam. (Belazi et al., 1994, p. 229)

(44) I'll take some naemaek.

'I'll take some salt'.

(Mahootian, 1993, p. 121)

With respect to Spanish-Korean CS data, we find that - as in English-Farsi CS switches can occur between quantifiers and nouns (ex. 45-47). What is also interesting 
is that bilinguals make use of number agreement; therefore, if it is plural, they add the suffix '-s' to the Korean noun, also violating the FMC (ex. 45-47). In our corpus, we also find switches between cardinal numbers and nouns (ex. 47).

(45) Muchos baksayng-s no vinieron al swuep.

[Venezuela]

'Many students didn't come to class'.

(46) Varios tongki-s se fueron al kwuntay.

[Spain]

'Several classmates went to the military service'.

(47) I twu mesas-lul pegar-hamyen todos se pueden sentar. [Colombia]

'If we put these two tables together, everyone can seat down'.

\section{Negation $+\mathbf{V}$}

Having considered several syntactic configurations where the FHC does not seem to hold crosslinguistically, let us turn to a final configuration that was believed to have no counterexamples in the crosslinguistic work on code-switching, namely the possibility of switching between negation and verb. According to Timm (1975), the verb and the negated word must be in the same language (ex. 48). Other researchers provide further evidence in favor of this restriction and claim that switches between negation and the main verb and between negation and an auxiliary verb are prohibited (ex. 49-50)

$$
\begin{aligned}
& \text { (48) *I don't quiero. } \\
& \text { (49) *I am no terca. } \\
& (50) * \text { Yo estoy not stubborn. }
\end{aligned}
$$$$
\text { (Timm, 1975, p. 479) }
$$$$
\text { (Woolford, 1983, p. 534) }
$$

However, yet again, both Spanish-Náhuatl CS and Spanish-Korean CS do allow switches between negation and verb. This is shown for Spanish-Náhuatl CS in (51), which has the Náhuatl negation followed by a Spanish verb. In Spanish-Korean CS, participants mixed the Spanish negation 'no' with Korean verbs and even Korean negation 'an' with Spanish verbs (ex. 52-53).

(51) Amo estoy tekititoc.

'I'm not working.' (MacSwan, 1999, p. 119)

(52) Hay que comer todo para no namkye porque mianhanikka. [Mexico] 
'We have to eat everything and don't leave leftovers because I feel bad.'

(53) Acik trotar an bako estirar-man haysse.

[Venezuela]

'I haven't jogged yet; I have only stretched.'

\section{Summary of Spanish-Korean CS}

The data presented so far shows that many of the constraints on code-switching that are (implicitly or explicitly) assumed to be universal are indeed not universal. In particular, it is interesting that our Spanish-Korean CS data have many similarities with MacSwan's (1999) data on Spanish-Náhuatl CS. When Spanish is mixed with Korean or with Náhuatl, many of the constraints proposed for Spanish-English code-switching seem to no longer apply.

The focus of our paper is to present empirical data illustrating how previously proposed constraints are violated in Spanish-Korean CS. Although we do not provide an in-depth analysis of what licenses these violations, we would like to suggest that these differences may be attributed to language family membership and associated typological differences, such as head position. For instance, typologically, Korean is a head-final language that belongs to the Koreanic family, whereas Spanish and English are IndoEuropean languages and typically categorized as head-initial. When the languages being switched have the same head-initial syntax - like Spanish and English - the word order does not change drastically since they languages have the same head directionality. However, when a head-initial and head-final language like Spanish and Korean are mixed, the word order becomes more flexible in code-switched utterances, because both types of constructions can be formed: Spanish can adapt to the Korean phrase structure, or vice versa. It seems that these word order differences may be responsible for at least some of the apparent 'violations' for the previously proposed constraints that we observe in the Spanish-Korean CS corpus.

What is perhaps surprising is the similarity Spanish-Korean CS has with SpanishNáhuatl CS. As a preliminary observation, we would like to suggest that this similarity arises because Náhuatl and Korean are both agglutinative languages with relatively free word order. Thus, they can combine easily with Spanish. The syntactic constraints on CS are 'weakened' in this situation, and both Korean and Náhuatl can combine different morphemes to novel roots (in this case Spanish words) allowing them to adopt better to Spanish grammar. 


\section{Constraints in Spanish-Korean CS}

Having noted that many of the constraints that govern Spanish-English CS do not apply to Spanish-Korean CS, it is nevertheless important to note that Spanish-Korean CS is not entirely unconstrained. It is not an "anything goes" of situation; switches are constrained. In this section, we focus on one constraint that governs Spanish-Korean switching, namely case-marking on pronouns. Since it is essentially impossible to get information about ungrammatical sentences through our naturalistic corpus data, in this section we consider examples from Park's (1990) study in English-Korean codeswitching.

\section{Pronouns with Case Markers in Korean}

Park (1990) looked at English-Korean CS and used acceptability judgment tasks to complement naturally-produced examples. He found that when English pronouns occurred with Korean case marking, the resulting switch was judged unacceptable. Intriguingly, three occurrences of such types (ex. 54) were found in Park's corpus data (Park 1990, p. 146).

(54) a. You-ka grammar teacher-nya?

'Are you (a) grammar teacher?'

b. They-tul-un courtesy-ka epseyo.

'They are not courteous.'

c. Him-eykey nemwu sorry-haysseyo.

'I was very sorry for him.'

Park (1990) did not classify sentences like (54) as ungrammatical because a fully fluent bilingual produced this kind of switches. However, in the acceptability task, English pronouns with Korean case-marking obtained the lowest ratings. This is interesting in light of the other cases (discussed in sections 5.3.1-5.3.7) where Spanish-Korean CS violated the FHC: There appears to be something special about pronouns and case-marking. Park's finding that pronoun-case-marker mixing is judged low in acceptability matches with other studies such as Berk-Seligson (1986), where the switch involving pronouns in Spanish-Hebrew was not frequent. Previously, McClure and Wentz (1975) had also proposed a prohibition on switches with pronouns, stating it as a universal theory in code-switching. 
In our corpus data, we find no examples of Spanish pronouns occurring with Korean case-marking, suggesting that this combination is probably unacceptable/ ungrammatical. Observe the following (constructed) examples of Spanish-Korean CS, where the Korean case marker is redundant. Perhaps the redundancy is what makes this switch unnatural:

(55) *iTú-ka bailaste con nay chinkwu?

'You danced with my friend?'

(56) *Ustedes-tuli nemwu sikkulewese no me concentro.

'I cannot concentrate because you people are very loud.'

There is still a great amount of work to do regarding data collection in SpanishKorean CS. The linguistic constraints in Spanish-Korean CS are mainly based on the structure conformity towards the head language and the avoidance of switches between pronouns and Korean case markers.

\section{Conclusions}

As observed in Table 2, language typology influences the morphosyntactic nature of possible switches.

Table 2. Náhuatl and Korean Language Typology

\begin{tabular}{|l|l|}
\hline Náhuatl & Korean \\
\hline Uto-Aztecan language & Language isolate (Koreanic) \\
Free word order & SOV order \\
(VSO as basic order) & Agglutinative morphology \\
Agglutinative morphology & Use of particles \\
Use of particles & \\
\hline
\end{tabular}

In the present study, we investigated the bilingual speech phenomenon, codeswitching, focusing on Spanish-Korean switches. We analyzed the linguistic constraints from the perspective of generative grammar and, to validate our data, we have shown counterexamples with the support of other language pairs as well. Our data suggests that, in comparison to Spanish-English CS, Spanish-Korean CS is subject to fewer constraints and seems to be more flexible. However, we would like to underline the importance of collecting more data from more participants and using a breadth of different methods of 
data collection. There is also a need to further investigate the constraints that do guide Spanish-Korean CS, in order to reach a more uniform and generalized theory that will account Spanish-Korean code-switching. Overall, through this preliminary study about Spanish-Korean code-switching, we have reached the conclusion that constraints that have been implicitly or explicitly viewed as 'universal' characteristics of code-switching may not be as universal as has been assumed in some prior work.

Going back to our research questions, we find that at least two of the linguistic constraints proposed for Spanish-English code-switching do not extend to Spanish-Korean code-switching: the Free Morpheme Constraint (FMC) and the Functional Head Constraint (FHC) are violated in Spanish-Korean code-switching. It is hard to assume universality of code-switching constraints given the evidence from different language pairs. Although our corpus seems to provide counterevidence for the constraints that have been proposed in the literature, this does not mean Spanish-Korean CS allows all kinds of switches. More future work is needed to better understand the constraints at play in Spanish-Korean CS.

The similarities between Spanish-Korean CS and Spanish-Náhuatl CS show that typology matters. Korean and Náhuatl are both agglutinative languages, and both languages allow switches with bound morphemes. Perhaps CS constraints should be based on language typology and not specific language sets. Moreover, it does not seem plausible to argue for fully universal theories of CS because the question of what kinds of switches are allowed seems to be influenced by several factors depending on the languages involved. To further discuss typology, we want to briefly mention Quechua-Spanish CS (e.g. Muntendam, 2006; Sánchez, 2012, among others). Quechua is an indigenous language family spoken in the regions of central Andes Mountains. Like Korean, Quechua has SOV word order and agglutinative morphology. Previous works on Quechua-Spanish CS have also reported utterances where Quechuan case markers are added to Spanish words. The following examples shows code-switching between Spanish nouns and Quechuan case markers.

(84) Aventaron en agua-ta.

Threw in water- ${ }_{\text {ACC }}$

'(They) threw (them) in the water' (Sánchez, 2012, p. 17)

(85) Chanta farol-sito-wan llojsi-mu-sqa dueña-n-qa .

Then lantern-DIM-INSTR come out-DIR-PAST 3 SG owner-POSS-TOP.

'Then her owner appeared with a small lantern'. (Muntendam, 2006, p. 2) 
Though still speculative at this point, evidence from three typologically agglutinative languages - Korean, Náhuatl, and Quechua - seems to show that it is indeed important to take typology into consideration. If this speculation is correct, we would also expect codeswitching between Aymara (another indigenous South American agglutinative language with SOV word order) and Spanish to yield similar patterns, where bilinguals mix Spanish nouns with Aymaran morphemes.

Additionally, Korean-English CS data have also been shown to allow switches inside a word by mixing English nouns with Korean case markers or Korean verbs with English verb endings like '-ing' (e.g. Park, 1990; Park, 2016; Kim \& Kaiser, 2019, among others). It is also important to look into phonology and language-specific phonotactic constraints, because bilinguals produce what is easily or comfortably pronounced, so certain structures are likely to be avoided due to phonotactics (e.g. Alexiadou, 2017; Kim \& Kaiser, 2019).

As for future work, we need to take a closer look at the constraints in SpanishKorean CS. We need to consider syntactic, morphological and phonological properties. Methodologically speaking, experimental work can help to corroborate observations based on corpus data.

\section{References}

Abney, S. (1987). The English Noun Phrase in its Sentential Aspect. Ph.D. Dissertation, MIT.

Alexiadou,A. (2017). Buildingverbs in language mixingvarieties. Zeitschriftfür Sprachwissenschaft, 36(1), 165-192. https://doi.org/10.1515/zfs-2017-0008

Alexiadou, A., \& Lohndal, T. (2018). Units of language mixing: A cross-linguistic perspective. Frontiers in psychology, 9. https://doi.org/10.3389/fpsyg.2018.01719

Belazi, H., Rubin, E., Toribio, A. (1994). Code Switching and X-Bar Theory: The Functional Head Constraint. Linguistic Inquiry, 25(2), 221-237.

Berk-Seligson, S. (1986). Linguistic Constraints on Intrasentential Code-switching: A Study of Spanish/Hebrew Bilingualism. Language in Society, 15, 313-348. https://doi.org/10.1017/ S0047404500011799

Bosque, I., Demonte, V., Lázaro Carreter, F., Pavón Lucero, M. V., \& Española, R. A. (1999). Gramática descriptiva de la lengua española. Espasa.

Chan, B. H. S. (2008). Code-switching, Word Order and the Lexical/Functional Category Distinction. Lingua, 118 (6), 777-809. https://doi.org/10.1016/j.lingua.2007.05.004 
Choi, J. (1991). Korean-English Code-switching: Switch-alpha and Linguistic Constraints. Linguistics, 29, 877-902. https://doi.org/10.1515/ling.1991.29.5.877

Chomsky, N. (1993). Language and Thought. London: Moyer Bell.

Cummins, J. (1981). The Role of Primary Language Development in Promoting Educational Success for Language Minority Students. Schooling and Language Minority Students: A Theoretical Framework, Sacramento: California State Department of Education, 3-49.

Fishman, J., Cooper, R., Ma, R., et al. (1971). Bilingualism in the Barrio. Indiana University Press.

Fishman, J. A. (1977). The social science perspective. In Bilingual Education: Current Perspectives. Social Science pp. 1- 49. Arlington, VA: Center for Applied Linguistics.

Giancaspro, D. (2013). L2 learners' and heritage speakers' judgments of code-switching at the auxiliary-VP boundary. In Selected Proceedings of the 16th Hispanic Linguistics Symposium, 56-69. Cascadilla Proceedings Project.

Gumperz, J. J. (1977). The Sociolinguistic Significance of Conversational Code-Switching. RELC Journal, 8(2), 1-34. https://doi.org/10.1177/003368827700800201

Joshi, A. K. (1985). Processing of Sentences with Intrasentential Codeswitching. Natural Language Parsing: Psychological, Computational, and Theoretical Perspectives, Cambridge University Press, 190-205. https://doi.org/10.1017/CB09780511597855.006

Kim, S. \& Kaiser, E. (2019). English-Korean code-switching: Looking beyond balanced bilinguals and beyond Indo-European. The 25th Architectures and Mechanisms of Language Processing Conference, Moscow, Russia. [talk]

Kwon, J. I. (2012). Hankuke munpepnon (Korean grammar). Seoul: Tae Hak Sa.

MacSwan, J. (1999). A Minimalist Approach to Intrasentential Code Switching. Garland.

McClure, E., \& Wentz, J. (1975). Code-switching among Mexican-American Children. Functionalism, Chicago: University of Chicago, 421-432.

Mahootian, S. (1993). A Null Theory of Codeswitching. Doctoral Dissertation, Northwestern University.

Mahootian, S., \& Santorini, B. (1996). Code-switching and the Complement/Adjunct Distinction. Linguistic Inquiry, 27(3), 464-479.

Martin, S. E. (1992). Yale romanization. A reference grammar of Korean, 8-12.

McClure, E. (1981). Formal and Functional Aspects of Codeswitched Discourse of Bilingual Children. Latino Language and Communicative Behavior, Ablex, 69-94. 
Muntendam, A. (2006). Diglossia, footing and Quechua-Spanish code-switching. In Symposium about language and society.

Nishimura, M. (1985). Intrasentential Code-switching in Japanese and English. Doctoral Dissertation, University of Pennsylvania.

Nishimura, M., \& Yoon, K. (1998). Head Directionality and Intrasentential Code-switching: A Study of Japanese Canadians and Korean Americans' Bilingual Speech. Japanese/Korean Linguistics 8, Stanford: CSLI Publications, 121-130.

Osawa, F. (1998). The Emergence of the D System and the Demise of Morphological Case in English. UCL Working Papers in Linguistics, 10, 467-488.

Park, J. (1990). Korean/English Intrasentential Code-switching: Matrix Language Assignment and Linguistic Constraints. Doctoral Dissertation, University of Illinois at Urbana-Champaign.

Park, K. (2016). A Constraint on Lexical Transfer, Journal of The Korea Society of Computer and Information, 21(11), 9-16. https://doi.org/10.9708/jksci.2016.21.11.009

Pfaff, C. (1979). Constraints on Language Mixing: Intrasentential Code-Switching and Borrowing in Spanish/English. Language, 55, 291-318. https://doi.org/10.2307/412586

Poplack, S. (1980). Sometimes I'll Start a Sentence in Spanish y termino en español: Toward a Typology of Code-switching. Linguistics, 18(7-8), 581-618. https://doi.org/10.1515/ ling.1980.18.7-8.581

Poplack, S. (1981). Syntactic Structure and Social Function of Codeswitching. Latino Language and Communicative Behavior, Norwood: Ablex, 169-184.

Potowski, K. \& Bolyanatz, M. (2012). Reactions to (in)felicitous codeswitching: Heritage speakers vs. L2 learners. In Selected Proceedings of the 14th Hispanic Linguistics Symposium, 116129. Cascadilla Proceedings Project.

Sánchez, L. (2012). Convergence in syntax/morphology mapping strategies: evidence from Quechua-Spanish code mixing. Lingua, 122(5), 511-528. https://doi.org/10.1016/j. lingua.2011.10.004

Sankoff, D., \& Poplack, S. (1981). A Formal Grammar for Code-Switching. Research on Language and Social Interaction, 14(1), 3-45. https://doi.org/10.1080/08351818109370523

Simpson, A. (2019). Language and Society: An Introduction. Oxford University Press.

Timm, L. A. (1975). Spanish-English Codeswitching: el porqué y How-not to. Romance Philology, $28,473-482$. 
Toribio, A. (2001). On the Emergence of Bilingual Code-switching Competence. Bilingualism: Language and Cognition, 4(3), 203-231. https://doi.org/10.1017/\$1366728901000414

Weinreich, U. (1953). Languages in contact. The Hague: Mouton.

Woolford, E. (1983). Bilingual Code-switching and Syntactic Theory. Lingusitic Inquiry, 14(3), 520-536.

Yoon, (1992). New Perspectives in Intrasentential Code-switching: A Study of Korean-English. Applied Psycholinguistics, 13, 433-449. https://doi.org/10.1017/S0142716400005750 